Research Artide

\title{
LEVEL OF CUSTOMER SATISFACTION IN TERMS OF SERVICES OFFERED BY SELECTED BANKS
}

\section{Archana Chaudhary*1 and Neelma Kunwar ${ }^{2}$}

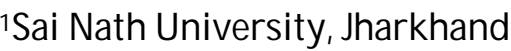 \\ ${ }_{2}^{2}$ College of H.Sc., CSAU, Kanpur, U.P
}

DOI: http://dx.doi.org/10.24327/ijrsr.2017.0805.0277

\section{ARTICLE INFO \\ Article History: \\ Received $18^{\text {th }}$ February, 2017 \\ Received in revised form $10^{\text {th }}$ \\ March, 2017 \\ Accepted $06^{\text {th }}$ April, 2017 \\ Published online $28^{\text {th }}$ May, 2017}

Key Words:

Level, customers, satisfaction

\begin{abstract}
In the Indian banking scenario, most public sector banks are referred to as nationalized banks. This classification is, however, inaccurate. According to the IMF (International Monetary Fund), "Nationalization" is defined as "government taking control over assets and over a corporation, usually by acquiring the majority or the whole stake in the corporation". In 1949, during the early years of the country's independence, India's central bank, the RBI (Reserve Bank of India) became the first bank to be nationalized. This was an important move since the RBI would soon become the regulatory authority for banking in India. Most Indian banks at that time were privately owned. Thus, the Indian government then recognized the need to bring them under some form of government control to be ale to finance India's growing financial needs.
\end{abstract}

Copyright (C) Archana Chaudhary and Neelma Kunwar, 2017, this is an open-access article distributed under the terms of the Creative Commons Attribution License, which permits unrestricted use, distribution and reproduction in any medium, provided the original work is properly cited.

\section{INTRODUCTION}

Banks have to deal with many customers every day and render various types of services to its customer. It's a well known fact that no business can exist without customers. Not so long ago, accessing our own money was about setting aside a couple of hours, getting to the bank before closing time, standing in one queue to get a token and then in another to collect the cash. Those were the pre-economic reforms days, when the banking sector primarily consisted of public sector banks. The banking industry like many other financial service industries is facing a rapidly changing market, new technologies, economic uncertainties, fierce competition and more demanding customers and the changing climate has presented an unprecedented set of challenges. Banking is a customer oriented services industry, therefore, the customer is the focus and customer service is the differentiating factors.The banking industry in India has undergone sea change since post independence. More recently, liberalization, the opening up of the economy in the 90 s and the governments' decision to privatize banks by reduction in state ownership culminated in the banking reforms based on the recommendations of Narasimha Committee. The prime mover for banks today is profit, with clear indications from the government to 'perform or perish'. Banks have also started realizing that business depends on client service and the satisfaction of the customer and this is compelling them to improve customer service and build up relationship with customers

\section{METHODOLOGY}

The study was conducted in Kanpur district. Seven nationalized banks were selected in this study. Total 100 customers were selected in this study area. Dependent and independent variables were used such as sex, education, income etc. and satisfaction, net banking, knowledge etc. The statistical tools were used such as weighted mean, S.D., Cr. etc.

\section{RESULTS}

Table 1 Distribution of bank customers according to age group

\begin{tabular}{cccc}
\hline Age group & Frequency & Per cent & Mean + SD \\
\hline 18 to 30 years & 11 & 11.0 & $25+3$ \\
30 to 40 years & 24 & 24.0 & $35+4$ \\
40 to 50 years & 39 & 39.0 & $46+3$ \\
50 to 60 years & 20 & 20.0 & $53+6$ \\
60 years \& above & 6 & 6.0 & $62+3$ \\
Total & 100 & 100.0 & $39+6$ \\
\hline
\end{tabular}

According to RBI rules all the adults can open their saving accounts and avail the benefits of all the policies running by the Banks but now below 18 years. However, they can open their minor accounts. ICICI and HDFC Banks are offering these services. Children older than 10 years will no longer need the help of their parents or guardians to open and operate a savings bank account. To boost financial inclusion, the Reserve Bank of India (RBI) permits the Banks to allow minors above 10 years to independently open and operate savings bank accounts. As of now, Banks allow minors to operate bank 
accounts only along with a parent or a guardian. All children and teenagers below the age of 18 are considered minors under current rules.

Table 2 Knowledge of the customers about the nationalized and private Banks in Kanpur district

\begin{tabular}{|c|c|c|c|c|}
\hline A. & Nationalized banks & Yes & No & Mean score \\
\hline 1. & State Bank of India & $72(72.0)$ & $28(28.0)$ & 1.72 \\
\hline 2. & Bank of Baroda & $64(64.0)$ & $36(36.0)$ & 1.64 \\
\hline 3. & Punjab National Bank & $68(68.0)$ & $32(32.0)$ & 1.68 \\
\hline 4. & Bank of India & $60(60.0)$ & $40(40.0)$ & 1.60 \\
\hline 5. & Central Bank of India & $66(66.0)$ & $34(34.0)$ & 1.66 \\
\hline 6. & Yes Bank & $41(41.0)$ & $59(59.0)$ & 1.41 \\
\hline 7. & Syndicate Bank & $38(48.0)$ & $62(62.0)$ & 1.38 \\
\hline 8. & Union Bank of India & $49(49.0)$ & $51(51.0)$ & 1.49 \\
\hline 9. & Canara Bank & $39(39.0)$ & $61(61.0)$ & 1.39 \\
\hline 10. & Bank of Maharashtra & $30(30.0)$ & $70(70.0)$ & 1.30 \\
\hline 11. & Indian Overseas Bank & $30(30.0)$ & $70(70.0)$ & 1.30 \\
\hline 12. & Allahabad Bank & $58(58.0)$ & $42(42.0)$ & 1.58 \\
\hline 13. & Oriental Bank of Commerce & $28(28.0)$ & $72(72.0)$ & 1.28 \\
\hline 14. & Indian Bank & $20(20.0)$ & $80(80.0)$ & 1.20 \\
\hline 15. & Corporation Bank & $28(28.0)$ & $72(72.0)$ & 1.28 \\
\hline 16. & Dena Bank & $26(26.0)$ & $74(74.0)$ & 1.26 \\
\hline 17. & UCO Bank & $35(35.0)$ & $65(65.0)$ & 1.35 \\
\hline 18. & Andhra Bank & $30(30.0)$ & $70(70.0)$ & 1.30 \\
\hline 19. & Vijya Bank & $29(29.0)$ & $71(71.0)$ & 1.29 \\
\hline B. & Private Banks & & & \\
\hline 1. & Axis Bank & $62(62.0)$ & $38(38.0)$ & 1.62 \\
\hline 2. & HDFC & $60(60.0)$ & $40(40.0)$ & 1.60 \\
\hline 3. & ICICI & $68(68.0)$ & $32(32.0)$ & 1.68 \\
\hline 4. & IDBI & $48(48.0)$ & $52(52.0)$ & 1.48 \\
\hline 5. & Kotak Mahindra & $20(20.0)$ & $80(80.0)$ & 1.20 \\
\hline 6. & IndusInd Bank & $10(10.0)$ & $90(90.0)$ & 1.10 \\
\hline 7. & Standard Chartered Bank & $12(12.0)$ & $88(88.0)$ & 1.12 \\
\hline 8. & Karnataka Bank & $10(10.0)$ & $90(90.0)$ & 1.10 \\
\hline 9. & Federal Bank & $18(18.0)$ & $82(82.0)$ & 1.18 \\
\hline 10 . & Karur Vysya Bank & $10910.0)$ & $90(90.0)$ & 1.10 \\
\hline 11. & Jammu and Kashmir Bank & $12(12.0)$ & $88(88.0)$ & 1.12 \\
\hline 12. & Brahmawart Commercial Bank & $8(8.0)$ & $92(92.0)$ & 1.08 \\
\hline 13. & South India Bank & $10(10.0)$ & $90(0.0)$ & 1.10 \\
\hline 14. & The Nainital Bank & $20(20.0)$ & $80(80.0)$ & 1.20 \\
\hline 15. & Bandhan Bank & $15(15.0)$ & $85(85.0)$ & 1.15 \\
\hline
\end{tabular}

There are total 35 banks and mostly people were having the knowledge about that but 100 per cent people were having the knowledge of selected banks.

Private banking is personalized financial and banking services offered to a bank's high net worth individuals (HNIs). In India, it is offered by foreign banks and a few private sector banks. Banks like Citibank, Standard Chartered, HSBC, HDFC, ICICI and the likes offer such services. The main advantage of private banking is that a dedicated relationship manager is assigned to the customer who takes care of all his/her banking and financial needs. Be it a simple thing like wanting cash delivered at our doorstep, or complex financial planning for kids, or retirement, drafting a will, investing short term surplus money, or buying a complex structured product- all of it is taken care of by the private banker. Table shows that customers liked the services of ICICI banks because ICICI banks are providing different schemes to customers and reminding the customers about the maturity dates of schemes by doing SMS also and customers like these services. Bank managers and bank employees are also motivating the customers about their new and different schemes.

Customer's numbers are normally not the same as account numbers, because a number of customer accounts can be linked to the one customer number. The customer number can be linked to any account that the customer controls, such as cheque, savings, loan, credit card and other accounts. Through Internet banking, one can keep an eye on transactions and account balance all the time. This facility also keeps the account safe. This means that by the ease of monitoring the account at anytime, one can get to know about any fraudulent activity or threat to the account before it can pose the account to severe damage. Mobile banking differs from mobile payments, which involves the use of a mobile device to pay for goods or services either at the point of sale or remotely, analogously to the use of a debit or credit card to effect

Table 3 Most preferred banking schemes and services by customers

\begin{tabular}{|c|c|c|c|c|c|c|c|}
\hline Schemes & SBI & PNB & BoB & HDFC & ICICI & OBC & IDBI \\
\hline - $\quad$ Saving account & 100.0 & 68.0 & 55.0 & 68.0 & 82.0 & 28.0 & 35.0 \\
\hline - Mutual fund & 30.0 & - & - & 90.0 & 92.0 & - & - \\
\hline - Recurring deposit & 70.0 & 52.0 & 40.0 & 68.0 & 72.0 & 15.0 & 42.0 \\
\hline - House loan & 82.0 & 12.0 & 22.0 & 66.0 & 60.0 & - & 6.0 \\
\hline - Educational loan & 40.0 & 32.0 & 18.0 & 77.0 & 80.0 & 5.0 & 8.0 \\
\hline - Car loan & 64.0 & 14.0 & 6.0 & - & 40.0 & - & - \\
\hline - Personal loan & 78.0 & 66.0 & 9.0 & 54.0 & 62.0 & - & 58.0 \\
\hline - ATM & 100.0 & 70.0 & 50.0 & 62.0 & 100.0 & 22.0 & 42.0 \\
\hline - Lockers & 100.0 & 80.0 & 62.0 & 66.0 & 60.0 & 6.0 & 8.0 \\
\hline - $\quad$ NRI account & 10.0 & - & - & - & 82.0 & - & - \\
\hline - Debit card & - & - & - & 22.0 & 44.0 & - & - \\
\hline - Current account & 22.0 & 18.0 & - & 32.0 & 41.0 & - & 20.0 \\
\hline - $\quad$ Fixed deposit & 90.0 & 30.0 & 32.0 & 46.0 & 81.0 & 22.0 & 40.0 \\
\hline - $\mathrm{RTGS/NIFT}$ & 62.0 & 31.0 & 28.0 & 42.0 & 70.0 & 20.0 & 30.0 \\
\hline - Net banking & 80.0 & 70.0 & 66.0 & 82.0 & 90.0 & 18.0 & 26.0 \\
\hline - Visa card & 20.0 & - & - & 66.0 & 86.0 & - & - \\
\hline - Overdraft against FD & - & - & - & 70.0 & 80.0 & - & - \\
\hline - Money transfer scheme & 25.0 & 30.0 & 32.0 & 50.0 & 52.0 & 8.0 & 9.0 \\
\hline - World Travel card & - & - & - & 62.0 & 76.0 & - & - \\
\hline - Gold loan & 66.0 & 52.0 & 50.0 & 60.0 & 55.0 & 12.0 & 16.0 \\
\hline - Car insurance & 60.0 & 38.0 & 34.0 & 46.0 & 52.0 & 8.0 & 15.0 \\
\hline - Life insurance & 70.0 & 40.0 & 42.0 & 80.0 & 88.0 & 18.0 & 40.0 \\
\hline - Health insurance & 66.0 & 42.0 & 45.0 & 74.0 & 84.0 & 20.0 & 25.0 \\
\hline - $\quad$ EFT Electronic fund & 70.0 & 48.0 & 47.0 & 72.0 & 86.0 & 16.0 & 20.0 \\
\hline - Minor saving account & 22.0 & 8.0 & 10.0 & 38.0 & 50.0 & - & 10.0 \\
\hline
\end{tabular}


Table 4 Advantages of selected Banks

\begin{tabular}{rrcc}
\hline Sl.No. & Schemes & Frequency & Per cent \\
\hline 1. & Internet banking & 50 & 50.0 \\
2. & Mobile banking & 30 & 30.0 \\
3. & ATM & 100 & 100.0 \\
4. & RTGS/NIFT & 100 & 100.0 \\
5. & SMS alert & 100 & 100.0 \\
6. & Balance enquiry of mobile & 15 & 15.0 \\
7. & Mini statement through mobile & 6 & 6.0 \\
8. & Better interest rate & 10 & 10.0 \\
9. & Need based account & 10 & 10.0 \\
10. & Domestic versus international account & 5 & 5.0 \\
11. & EFT (Electronic Fund transfer) to other people's account & 22 & 22.0 \\
12. & Debit card & 60 & 60.0 \\
13. & Educational loan & 100 & 100.0 \\
14. & House loan & 100 & 100.0 \\
15. & Car loan & 100 & 100.0 \\
\hline
\end{tabular}

an EFTPOS payment. One can do most of the banking transaction after banking hours from anywhere. All ATM machines, at a minimum, permit cash withdrawals of customers of the machine's owner (if a bank-operated machine) and for cards that are affiliated with any ATM network the machine is also affiliated. The NEFT is a nationwide payment system facilitating one to one funds transfer. Under this system, individuals, firms and corporate can electronically transfer funds from any bank branch to any individual, firm or corporate having an account with any to bank branch in the country participating in the system. Benefits of using SMS for alert such as broadcast to large groups instantly receive delivery notifications, low cost, fast and easy to use. Automated communication with a large number of employees, volunteers, customers, members and citizens facilitates the mitigation of problems quickly and effectively. A student loan is designed to help students pay for university tuition, books, and living expenses. It may differ from other types of loans in that the interest rate may be substantially lower and the repayment schedule may be deferred while the student is still in school. It also differs in many countries in the strict laws regulating renegotiating and bankruptcy. Usually, a home loan is one of the biggest liabilities. Considering the huge amount and the long tenure involved. However home loan also offers some benefits.

Table 5 Level of customer satisfaction in terms of services offered by selected Banks

\begin{tabular}{ccccc}
\hline \multirow{2}{*}{ Sl. No. } & \multirow{2}{*}{ Name of Bank } & \multicolumn{3}{c}{ Performance } \\
\cline { 2 - 5 } & & Good & Very Good & Average \\
\hline 1. & SBI & 6.0 & 90.0 & 2.0 \\
2. & ICICI & 12.0 & 84.0 & - \\
3. & PNB & 15.0 & 72.0 & 8.0 \\
4. & Bank of Baroda & 14.0 & 84.0 & 13.0 \\
5. & HDFC & 20.0 & 70.0 & 10.0 \\
6. & Oriental Bank of Commerce & 10.0 & 80.0 & 10.0 \\
7. & IDBI & & \\
\hline
\end{tabular}

The working of the customers' mind is a mystery which is difficult to solve understanding the nuances of what customer satisfaction is a challenging task. This exercise in the context of the banking industry will give us an insight into the parameters of customer satisfaction and their measurement.

\section{CONCLUSION}

The management should understand the benefits of service quality. It include increased customer satisfaction, improved customer retention, positive word of mouth, reduced staff turnover, decreased operating costs, enlarged market share, increased profitability and improved financial performance. In the days of intense competition, superior service is the only differentiator left before the banks to attract, retain and partner with the customers. Superior service quality enables a firm to differentiate itself from its competition, gain a sustainable competitive advantage and enhance efficiency. Thus improving service quality leads to the customer satisfaction and ultimately to customer loyalty.

\section{Recommendations}

1. Educate customers on financial literacy.

2. Create real customer relationship.

3. Encourage positive attitudes for customers.

4. Be sensible about customer's expectations.

5. Customer service committee.

\section{References}

1. Naveen, K and Gangal, V.K. (2011). Customer satisfaction in New Generation Banks: A case study of HDFC Bank. International Referred Research Journal, 11(4): 177-186.

2. Nirmaljeet, V. and Prabhjot, K.M. (2012). "Customer satisfaction: A comparative analysis of public and private banks in India. Information and Knowledge Management, 2(3):1.

3. Padhy (2009). A study on customer satisfaction and service gaps in selected private, public and foreign banks retrieved from http://unpan1.un.org./ intradoc/ groups/pulic/documents/apcity/unpan047385.pdf.

4. Richard (2013). Factors that determine customer satisfaction level in banking institutions: evidence from Ghanaian banking industry. Asian Journal of Business and Management Sciences, ISSN: 20472528, 2(7): 1-13.

\section{How to cite this article:}

Archana Chaudhary and Neelma Kunwar.2017, Level of Customer Satisfaction In Terms of Services offered By Selected Banks. Int J Recent Sci Res. 8(5), pp. 17079-17081. DOI: http://dx.doi.org/10.24327/ijrsr.2017.0805.0277 